\title{
ANAK DAN HAK PENDIDIKANNYA DI MASA PANDEMI COVID-19 STUDI DUSUN CIPUTAT, DESA BOJONG KECAMATAN BUNGBULANG, KABUPATEN GARUT
}

\author{
Sulistyary Ardiyantika \\ Politeknik Kesejahteraan Sosial Bandung. Ardiyantika@ poltekesos.ac.id
}

\begin{abstract}
The sudden emergence of the Covid-19 Virus in Indonesia has changed all the orders of human life, one of which is in the world of education. The state is trying to take action to overcome the impact of this pandemic, especially in education so that the system for fulfilling the right to education can continue to be fulfilled, specifically related to children's education. This study aims to describe how the education system was carried out in Ciputat village during the Pandemic. As is known, the village has limited electronic media and internet access to provide online education according to a decision made by the Minister of Education some time ago. This study uses a qualitative research method with a descriptive approach. The results of the analysis of this study found that the fulfillment of the right to education involves good cooperation from several parties, both at the school, family, community and local government levels. So that this condition has a good impact in supporting children's education amid limited access during the current Covid-19 pandemic, although it is not yet fully perfect but is good enough in dealing with children's education.
\end{abstract}

\section{Keywords:}

Right to education; Child; Covid-19 pandemic

\begin{abstract}
Abstrak
Kemunculan Virus Covid-19 di Indonesia secara tiba-tiba telah merubah segala tatanan kehidupan manusia salah satunya dalam dunia pendidikan. Negara dipaksa untuk secepatnya mengambil tindakan guna menanggulangi dampak dari Pandemi ini terutama dalam bidang pendidikan agar sistem pemenuhan hak Pendidikan dapat terus terpenuhi khususnya terkait pendidikan anak. Adapun penelitian ini bertujuan untuk mendeskripsikan bagaimana sistem pendidikan yang dilakukan dusun Ciputat di masa Pandemi. Seperti yang diketahui dusun tersebut memiliki keterbatasan media elektronik maupun akses internet untuk menyelenggarakan pendidikan secara Daring atau Online sesuai keputusan yang dibuat Menteri Pendidikan beberapa waktu lalu. Penelitian ini menggunakan metode penelitian kualitatif dengan pendekatan deskriptif. Hasil analisa dari penelitian ini diperoleh bahwa pemenuhan hak pendidikan melibatkan kerjasama yang baik dari beberapa pihak baik tingkat sekolah, keluarga, masyarakat serta pemerintah setempat. Sehingga kondisi ini berdampak baik dalam mendukung pendidikan anak ditengah keterbatasan akses di masa pandemic Covid-19 saat ini
\end{abstract}


meskipun belum sepenuhnya sempurna akan tetapi sudah cukup baik dalam memenuhi kelangsungan pendidikan anak.

Kata Kunci:

Hak pendidikan; Anak; Pandemi Covid-19 


\section{PENDAHULUAN}

Di penghujung tahun 2019, tepatnya 31 Desember, WHO China Country Office melaporkan sebuah kasus pneumonia di kota Wuhan Provinsi Hubei, China. Pada tanggal 7 Januari 2020, China kemudian mengidentifikasi pneumonia yang tidak diketahui etiologinya tersebut sebagai jenis baru coronavirus (novel coronavirus) yang disingkat Covid-19. Kemudian Pada tanggal 30 Januari 2020, WHO menetapkan COVID-19 sebagai Public Health Emergency of International Concern (PHEIC) atau Kedaruratan Kesehatan Masyarakat yang meresahkan Dunia (KKMMD). (Tim Kerja Kementerian Dalam Negeri, 2013)

Peningkatan penyebaran kasus Covid19 berlangsung cukup cepat di seluruh penjuru dunia tanpa terkecuali di Indonesia. Indonesia mencatat kasus pertama kali ditemukan pada tanggal 02 Maret 2020 dari kota Depok dan diumumkan langsung oleh presiden Joko Widodo di Istana Negara. (Nasional Kompas: 2020). Sejak terjadinya kasus pertama tersebut, kurva penyebaran dan penularan Virus Covid19 terus mengalami peningkatan pesat dan signifikan setiap harinya. Bersamaan dengan itu dikeluarkanlah Keputusan Menteri Kesehatan Republik Indonesia Nomor Hk.01.07/Menkes/104/2020 tentang: Penetapan Infeksi Novel Coronavirus (Infeksi 2019-Ncov) sebagai Penyakit yang dapat menimbulkan wabah dan upaya penanggulangannya. (Kemenkes RI, 2020). Pemerintah Indonesia pun mengeluarkan status darurat bencana terhitung sejak tanggal 29 Februari 2020 hingga 29 Mei 2020. (News.detik: 2020). Kemudian sesuai Keputusan Presiden Nomor 12 Tahun 2020 ditetapkan bahwa Corona Virus Disease 2020
(Covid-19) sebagai Bencana Nasional Non Alam. (Media Indonesia: 2020)

Kondisi tersebut menjadi tantangan besar bagi penduduk Indonesia, pasalnya pemerintah saat ini dihadapkan tantangan yang kompleks yakni menangani pandemi kesehatan dan di saat bersamaan harus mengatasi dampak sosial, ekonomi serta psikologis masyarakat. (Tim Kerja Kementerian Dalam Negeri, 2013). Ancaman yang menakutkan ini perlu dihadapi melalui kebijakan yang kuat dan terkoordinasi mengingat virus Covid-19 merupakan jenis virus baru sehingga belum ada persiapan khusus terkait penyelesaian permasalahannya. Ketidaksiapan masyarakat dalam menghadapi perubahan tersebut tentunya dapat menimbulkan dampak krisis yang signifikan. Di luar hilangnya nyawa manusia secara tragis, krisis ini juga menimbulkan kerugian dalam berbagai aspek seperti meningkatnya angka kemiskinan dan ketidaksetaraan serta berdampak lebih kepada kelompok rentan. (International Labour Organization, 2020).

Begitu besarnya dampak yang ditimbulkan akibat pandemi Covid-19 selain sudah merenggut jutaan korban jiwa, juga banyak usaha mengalami keterpurukan, angka pengangguran meningkat, pekerja informal semakin tercekik, para dokter dan tenaga medis berguguran, siswa sekolah harus belajar dari rumah, dan masih banyak dampak lainnya. Salah satu yang terdampak besar akibat pandemic Covid-19 yaitu dalam bidang pendidikan. Sesuai dengan arahan Menteri Pendidikan dan Kebudayaan Republik Indonesia terkait Surat Edaran Nomor 4 Tahun 2020 tentang Pelaksanaan Kebijakan Pendidikan dalam Masa Darurat Penyebaran Corona Virus Disease (Covid19).(Mendikbud, 2020) 
1. Belajar dari Rumah melalui pembelajaran daring/jarak jauh dilaksanakan untuk memberikan pengalaman belajar yang bermakna bagi siswa, tanpa terbebani tuntutan menuntaskan seluruh capaian kurikulum untuk kenaikan kelas maupun kelulusan;

2. Belajar dari Rumah dapat difokuskan pada pendidikan kecakapan hidup antara lain mengenai pandemi Covid-19;

3. Aktivitas dan tugas pembelajaran Belajar dari Rumah dapat bervariasi antarsiswa, sesuai minat dan kondisi masing-masing, termasuk mempertimbangkan kesenjangan akses/fasilitas belajar di rumah;

4. Bukti atau produk aktivitas Belajar dari Rumah diberi umpan balik yang bersifat kualitatif dan berguna dari guru, tanpa diharuskan memberi skor/nilai kuantitatif.

Aktifitas sekolah yang biasanya ramai dengan hiruk pikuk siswa kini sepi dikareakan siswa dianjurkan untuk bersekolah dari rumah menggunakan media daring atau secara online. Bagi sebagian siswa yang berada di perkotaan, kondisi tersebut tentunya tidak terlampau sulit untuk dijalani karena mereka sudah terbiasa menggunakan alat teknologi canggih seperti laptop dan HP android serta terbiasa berjibaku dengan sinyal internet. Tetapi berbeda halnya bagi siswa yang berada di wilayah pedesaan. Para siswa yang tinggal di desa memiliki keterbatasan dalam bidang teknologi guna mengakses pendidikannya secara daring atau online. Seperti yang diberitakan di media tentang bagaimana perjuangan para siswa untuk memperoleh hp android agar bisa belajar online, mencari sinyal ke dataran tinggi hingga menginap di balai desa untuk mendapatkan jaringan internet dan masih banyak cerita lainnya.
Melihat kondisi pandemi Covid-19 yang belum diketahui kapan akan berakhir menjadi tantangan bagi semua pihak sebab proses pembelajaran dari rumah belum pernah terukur dan teruji sebelumnya. Guna mewujudkan hal tersebut, diperlukan strategi khusus untuk memenuhi hak pendidikan para siswa terutama bagi mereka yang berada di wilayah dengan fasilitas terbatas untuk melakukan pembelajaran secara daring seperti para siswa yang tinggal di pedesaan. Di tengah keterbatasan akses tersebut, baik guru, orangtua maupun lingkungan sekitar hendaknya bersinergi saling bahu membahu mewujudkan hak pendidikan anak di masa pandemi Covid-19. Dalam penelitian ini, ingin mencari tahu bagaimana implementasi pemenuhan kebutuhan pendidikan anak di masa Pandemi Covid-19 terutama bagi mereka yang berada di wilayah pedesaan sehingga kebutuhan pendidikan mereka juga dapat terpenuhi seperti siswa-siswa di perkotaan lainnya.

\section{METODE}

Penelitian ini menggunakan pendekatan kualitatif, yang mempelajari, menggambarkan dan mengamati bagaimana implementasi pemenuhan hak pendidikan anak yang dilakukan di dusun Ciputat, Desa Bojong, Bungbulang Garut di masa pandemi Covid-19 ini. (Creswell, 2009).

Penelitian ini menggunakan jenis penelitian deskriptif. Menurut Neuman (2006: 35) yang menyajikan gambaran yang terperinci tentang suatu situasi sosial, setting sosial atau hubungan sosial. Data yang didapat, disusun dan diolah kemudian dianalisa untuk mendapatkan gambaran apa adanya mengenai sebuah fenomena yang diteliti. Dengan 
menggunakan deskriptif, didapatkan gambaran lebih lanjut mengenai perubahan sistem pendidikan yang dilakukan pada masa Pandemi Covid-19 di Dusun Ciputat. Selain itu, teknik pengumpulan data menggunakan wawancara, observasi dan dokumentasi.

Data yang diperoleh diuji melalui triangulasi, yaitu strategi yang kuat untuk meningkatkan kualitas penelitian. Triangulasi dilakukan dengan dua cara yaitu dengan data dan sumber data. Menggunakan Triangulasi data, penulis mengumpulkannya dengan cara dibandingkan (misalnya, data dari wawancara terstruktur, observasi partisipatif, sejarah kehidupan). Triangulasi sumber data, dengan memaksimalkan jangkauan data yang mungkin berkontribusi untuk menyelesaikan pemahaman konsep. (Krefting, 1991).

\section{HASIL PENELITIAN}

Sejak kemunculan virus Covid 19 sejak akhir tahun 2019 yang lalu, seluruh tatanan kehidupan mengalai perubahan dan penyesuaian secara cepat agar roda kehidupan terus berputar. Berbagai inovasi baru pun turut diciptakan untuk mencegah stagnansi kehidupan akibat pandemi ini. Salah satu sektor yang harus secepatnya memutar otak untuk mencari inovasi baru adalah lembaga pendidikan. Setelah pemerintah mengumumkan darurat Covid-19 pada bulan Maret 2020 lalu, Menteri pendidikan kemudian mengumumkan kebijakan baru belajar dari rumah untuk mencegah kluster baru penyebaran Virus Covid-19.

Dalam Surat Edaran Nomor 4 Tahun 2020 tentang Pelaksanaan Kebijakan Pendidikan dalam Masa Darurat Penyebaran Corona Virus Disease (Covid-19) Pada poin 2 yang berbunyi:
Proses Belajar dari Rumah dilaksanakan dengan ketentuan sebagai berikut:

a. Belajar dari Rumah melalui pembelajaran daring/jarak jauh dilaksanakan untuk memberikan pengalaman belajar yang bermakna bagi siswa, tanpa terbebani tuntutan menuntaskan seluruh capaian kurikulum untuk kenaikan kelas maupun kelulusan;

b. Belajar dari Rumah dapat difokuskan pada pendidikan kecakapan hidup antara lain mengenai pandemi Covid-19;

c. Aktivitas dan tugas pembelajaran Belajar dari Rumah dapat bervariasi antar siswa, sesuai minat dan kondisi masing-masing, termasuk mempertimbangkan kesenjangan akses/fasilitas belajar di rumah;

d. Bukti atau produk aktivitas Belajar dari Rumah diberi umpan balik yang bersifat kualitatif dan berguna dari guru, tanpa diharuskan memberi skor/nilai kuantitatif.

Sekolah dasar Negeri 1 Bojong merupakan salah satu sekolah yang juga terdampak dalam bidang pendidikan akibat penyebaran virus covid-19 yang maa mayoritas siswanya berasal dari Dusun Ciputat karena lokasi sekolah tersebut berada disana. Sekolah dasar yang terletak di Dusun Ciputat, Desa Bojong ini dengan terpaksa tidak dapat mengikuti pendidikannya secara daring atau online sesuai dengan instruksi yang diberikan oleh Menteri Pendidikan dan Kebudayaan RI. Pasalnya sekolah yang berada di daerah ujung Kabupaten ini memiliki fasilitas yang belum memadai untuk melaksanakan sistem pembelajaran secara daring. Dengan demikian secara terpaksa sekolah harus menyelenggarakan pendidikan secara offline dengan tidak lupa menerepkan protokol kesehatan yang berlaku. Dusun 
Ciputat tergolong sangat minim akses internet, dari 112 siswa yang kini bersekolah disitu, hanya $3 \%$ saja siswanya yang memiliki ponsel android. Sehingga pihak sekolah dan UPT sekolah membuat kebijakan lain untuk mewujudkan hak pendidikan anak meskipun dalam suasana pandemi sebab mereka tidak dapat mengandalkan pembelajaran secara online. Demi mewujudkan pemerataan pendidikan di masa pandemi di Ciputat, Desa Bojong, sesuai dengan yang tertuang dalam Konvensi hak Anak tentang perolehan kesempatan dan fasilitas yang dijamin oleh hukum dan sarana lain sehingga secara jasmani, mental, akhlak rohani sosial, mereka dapat berkembang dengan sehat dan wajar, baik sekolah, pemerintah desa dan orangtua siswa turut bekerjasama mewujudkan pendidikan terbaik bagi para siswa. Jangan sampai dengan adanya pandemi Covid 19, hak belajar siswa menjadi terabaikan.

\section{PENDIDIKAN SEKOLAH}

Sekolah merupakan sektor pertama yang menjadi tujuan pendidikan bagi para peserta didik. Di Indonesia, sejak bertahun tahun serta menjadi sebuah rutinitas wajib bahwasanya sekolah menyelenggarakan pendidikan secara offline manakala guru bertatapan langsung dengan siswanya melaksanakan interaksi pembelajaran. Sekolah dengan cara bertatap muka dianggap menjadi strategi terbaik yang dapat digunakan untuk menyerap pengetahuan dari guru dalam proses pentransferan ilmu. Akan tetapi pada awal 2020 sejak kemunculan Pandemi Covid-19 di Indonesia, pemerintah mewajibkan siswanya melakukan pembelajaran secara online atau daring dari rumah agar mengurangi penyebaran virus. Satu sistem pembelajaran yang tentunya sangat awam di kalangan masyarakat pada umumnya apalagi mereka yang tinggal di pedesaan.

Berdasarkan surat edaran yang sudah dibuat pemerintah pada bulan Maret tahun 2020 lalu terkait dengan pembelajaran online, pihak sekolah di SDN 1 Bojong tidak dapat menerapkan sistem pendidikan secara online tersebut dikarenakan beberapa kendala. Mereka terpaksa harus tetap menerapkan sistem pembelajaran secara offline tanpa melanggar aturan-aturan protokol kesehatan yang berlaku. Kebijakan sekolah untuk melaksanakan pendidikan secara online dibuat dengan beberapa pertimbangan serta alasan diantaranya keterbatasan sarana dan prasarana untuk melaksanakan pendidikan secara online seperti Laptop, ponsel android, kuota, sinyal dan lain sebagainya. Selain itu kapasitas dari pengajarnya juga menjadi salah satu penghambat sehingga pelaksanaan pembelajaran secara online tidak bisa dijalankan. Sebagian besar dari pengajar yang ada di SDN 1 Bojong adalah guru senior yang kurang begitu memahami cara penggunaan teknologi. Ketidaksiapan tersebut membuat pihak sekolah harus menggunakan sistem pembelajaran secara offline dalam memenuhi hak pendidikan siswa.

Wawancara dengan kepala sekolah ibu O:"

"iya neng, kita buat kebijakan sendiri dari sekolah biar seperti ini. Anak-anak disini hanya sedikit sekali yang punya hape, mah kalau ngikutin seperti perintah Menteri tetap gak bisa atuh neng. Kita 
tinggalnya di desa, apa apa serba terbatas kalau mau ngikutin pemerintah".

Tanpa melanggar protokol kesehatan yang telah dibuat pemerintah, sistem pembelajaran dilaksanakan dengan cara shift setiap minggunya. Pembagian sift kelas tersebut bertujuan untuk mengurangi kerumunan siswa yang datang ke sekolah. Sebab tidak bisa dipungkiri, social distancing atau jaga jarak di kalangan anak-anak tentunya lebih sulit terhindarkan karena masa kanak-kanak cenderung suka bermain bersama temantemannya.

Adapun pembagian jadwal kelasnya sebagai berikut:

\begin{tabular}{|l|l|l|}
\hline No & \multicolumn{1}{|c|}{ Hari } & \multicolumn{1}{c|}{ Kelas } \\
\hline 1. & Senin & Kelas I dan kelas II \\
\hline 2. & Selasa & Kelas III dan Kelas IV \\
\hline 3. & Rabu & Kelas V dan kelas VI \\
\hline 4. & Kamis & Kelas I dan kelas II \\
\hline 5. & Jumat & Kelas III dan Kelas IV \\
\hline 6. & Sabtu & Kelas V dan kelas VI \\
\hline
\end{tabular}

Setiap hari, Jam sekolah mereka dimulai pada pukul 08.00 WIB. Sebelum memasuki ruang kelas, seluruh siswa diwajibkan mengecek suhu tubuh, mencuci tangan terlebih dahulu dan menggunakan faceshield yang disediakan sekolah. Kemudian pembelajaran dimulai pada pukul 08.30 WIB dan berakhir pada pukul 12.00 WIB. Seperti tabel yang sudah penulis jabarkan di atas, setiap hari masingmasing kelas diberikan kesempatan untuk hadir di sekolah sebanyak dua kali dalam satu minggu.
Menurut pengajarnya, pembagian kelas yang dilakukan bertujuan untuk meminimalisir kerumunan dari para siswa. Cara ini dianggap lebih maksimal dari pada siswa tidak ke sekolah sama sekali sebab jika para guru mengandalkan sistem pembelajaran secara online akan sulit terealisasi. Pembelajaran pun dilakukan seperti biasa oleh para guru kepada siswanya meskipun dengan jam yang tidak maksimal seperti jam belajar normal mereka sebelum adanya pandemi Covid-19. Guna memenuhi target pembelajaran, para guru memberikan tugas tambahan atau pekerjaan rumah kepada siswa untuk dikerjakan dirumah dan dikumpulkan saat masuk ke sekolah kembali di jadwal berikutnya. Tugas yang diberikan pun intensitasnya lebih banyak dari tugas biasa saat sebelum pandemi. Sehingga untuk mencapai target pembelajaran siswa yang maksimal, para guru sangat mengharapkan peran serta para orangtua untuk mengawasi serta mendampingi anak mereka untuk belajar di rumah.

Ketika peneliti mencoba mewawancarai ibu guru $\mathrm{N}$ sebagai berikut:

"siswa dalam satu minggu masuknya tiap 2 hari sekali teh, sebelum masuk kelas mereka kita bariskan dulu cuci tangan dan lain-lain kemudian masuk ke kelas". di dalam kelas pelajarannya sama seperti biasanya, cuman PR nya ditambahin lebih banyak buat dikerjakan kalau pas dirumah masing-masing." 
Perihal efektifitas pelaksanaan sekolah secara luring, para guru memang lebih setuju dengan melaksanakan pendidikan secara luring atau bertatapan langsung. Sebab jika menggunakan media online tidak memungkinkan bagi para siswa mereka dengan segala keterbatasan fasilitas yang ada. Meskipun pembelajaran luring atau bertatap muka yang dilakukan saat ini menjadi solusi alternatif terbaik yang harus dipilih, dalam hal substansi lainnya seperti materi pembelajaran, keterbatasan waktu pembelajaran, belajar praktek sehingga berpengaruh pada tidak terpenuhinya target SOP. Selain itu ada perasaan was-was dan khawatir ditengah pandemi yang masih mengganas, ketakutan jika terjadi hal yang tidak diinginkan pada sekolah dan siswa mereka. Guna mencegah pelanggaran protokol kesehatan, para guru selalu disiplin menegakkan 5M kepada para siswa jika akan memasuki ruangan kelas untuk melakukan pembelajaran. Kerjasama dan dukungan dari seluruh pihak sangat dibutuhkan untuk mencegah hal-hal yang tidak diinginkan.

Saat dilihat dari perspektif siswa, kegiatan belajar mengajar secara luring atau bertatap muka juga mendapat respon baik dari mereka. Meskipun pembelajaran saat ini menurut mereka lebih terasa "ribet" tetapi menyenangkan karena tetap bisa bertemu secara langsung dengan guru dan teman-teman mereka.
Seperti yang diungkapkan SF yang saat ini tengah duduk di bangku kelas VI SDN 1 Bojong:

" seru kak sudah bisa ke sekolah lagi ketemu teman-teman. Sebelum masuk ke kelas diperiksa dulu, pake yang buat nutup muka trus duduknya jauhjauhan. Kalau kita ngobrol deket deketan gitu suka dimarahin sama bu guru disuruh jaga jarak kak”.

Dari pemaparan SF dapat ditarik sebuah gambaran bahwasanya belajar secara bertatap muka lebih menyenangkan. Hanya saja sekolah di masa pandemi tugasnya lebih banyak daripada sekolah biasanya terdahulu. Sebab target guru untuk mengajarkan materi 1 semester tidak dapat tercapai secara maksimal jika hanya masuk sekolah 1 minggu sebanyak 2 kali. Guna memenuhi target pembelajaran tersebut, para guru memberikan tugas lebih banyak sehingga anak bisa belajar dirumah didampingi orangtua mereka.

Adik kelas SF yang saat ini kelas IV yang juga ditemui secara bersamaan mengungkapkan kondisi tersebut:

"tapi kalau sekolah sekarang tugasnya lebih banyak kak, lebih sulit karena gak dijelasin dulu sama bu guru. Jadi kalau tugasnya susah nanyanya suka sama mamah, tapi mamah kadang gabisa bantuin, jadinya ngerjainnya sebisanya atau gak pergi bertanya kerumah bu guru".

Meskipun tingkat keefektifan dari belajar secara luring di tengah pandemi ini masih sangat kurang, akan tetapi 
setidaknya para siswa tetap dapat memperoleh pendidikan yang diberikan oleh guru. Sebab para siswa yang tinggal di desa tidak sedikit yang memiliki perspektif bahwa belajar efektif ya di sekolah.

\section{PENDIDIKAN DARI RUMAH}

Demi menunjang ketercapaian target pemenuhan hak pendidikan anak, keterlibatan keluarga dalam membimbing anak belajar sangatlah penting. Apalagi dalam situasi pandemi saat ini, pihak orangtua harus memberikan perhatian ekstra bagi putra/putri mereka yang sedang menempuh pendidikannya disamping tugas orangtua dalam menjaga kesehatan anggota keluarganya dari resiko terpapar Virus yang sedang mewabah saat ini. Semenjak kemunculan pandemi Covid -19 di Indonesia, lembaga pendidikan dengan secepatnya melakukan transformasi sistem pembelajaran sementara dengan belajar secara daring atau online. Seluruh aktifitas pembelajaran yang biasanya dilaksanakan di sekolah, kini berbanding terbalik harus dilaksanakan dari rumah sesuai arahan Menteri Pendidikan.

Meskipun sistem pembelajaran secara online tidak diterapkan di sekolah SDN 1 Bojong, namun tantangan belajar yang dirasakan oleh orangtua siswa juga tidak kalah luar biasa. Ketika peneliti menanyakan kepada orangtua mereka, hampir seluruh dari mereka turut juga merasakan stres. Betapa tidak, fasilitas pembelajaran yang kurang mumpuni, tingkat kesibukan para orangtua yang mayoritas memiliki mata pencaharian sebagai petani, serta tingkat pengetahuan yang masih minim juga menjadi hambatan tersendiri bagi mereka. Dalam sebuah kesempatan, Orangtua SF pernah bercerita betapa kerepotannya mereka saat mendampingi anak sekolah di rumah. Istilah khasnya" yang sekolah anaknya, tapi yang ikut pusing mamahnya". Orangtua SF menceritakan bahwa beliau kesulitan dalam mendampingi anaknya belajar.

" duhh teh, si SF kan sekarang udah kelas VI, jadi pelajarannya juga agak sulit, jadi saya bingung kadang kalau ditanyain cara ngerjain soal. ya kasian juga kalau engga bisa bantuin, jadi kadang SF pergi ke rumah bu gurunya buat nanya".

Akan tetapi menurut mereka hal ini sebenarnya lebih baik karena ada interaksi anak-anak belajar di sekolah bersama gurunya. Paling tidak kalau gurunya sudah memberikan tugas anak akan lebih bersemangat mengerjakan. Di saat awal mula akan dilaksanakan pembelajaran, para orangtua siswa juga diminta datang ke sekolah untuk mengikuti sosialisasi terkait pentingnya peran serta orangtua atau keluarga dalam mendampingi anak belajar dirumah guna memenuhi target pendidikan para siswa. 


\section{KETERLIBATAN MASYARAKAT TERKAIT PENDIDIKAN ANAK}

Lingkungan sangat mempengaruhi bagaimana tumbuh kembang anak. Di masa pandemi Covid-19 yang sedang melanda warga masyarakat saat ini, peran serta dan kerjasama dari masyarakat sekitar sangat bergantung dalam mensukseskan anak-anak dalam meraih pendidikannya. Seperti yang yang dilakukan di Dusun Ciputat, Desa Bojong Kecamatan Bungbulang Garut. Meskipun kebijakan untuk siswa belajar dari rumah sedang digalakkan pemerintah saat ini, akan tetapi daerah tersebut tetap mempertahankan kondisinya untuk terus belajar dari sekolah dengan segala keterbatannya serta tetap mempertahankan protokol kesehatan. Karena belajar dari sekolah selama pandemi ini dibatasi jam belajar yang lebih singkat, pihak sekolah dengan masyarakat turut bekerja sama mencari strategi untuk memenuhi hak pendidikan anak yang terbatas diperoleh di sekolah.

Adapun beberapa strategi yang digunakan masyarakat untuk memenuhi hak pendidikan anak adalah:

1. Demi mendukung kelancaran pembelajaran, anak-anak wajib belajar dirumah sejak pukul 19.00-selesai dengan didampingi orangtua masing-masing.

2. Pemerintah desa memberikan fasilitasi belajar kelompok kepada anak-anak di masing-masing dusun salah satunya Dusun Ciputat dengan fasilitasi yang lengkap untuk tempat belajar bersama.

Pemberian pembatasan interaksi diluar wilayah desa selain bertujuan untuk mencegah penularan virus Covid-19 juga untuk menggiatkan para peserta didik agar tertib belajar di rumah dengan harapan target pendidikan mereka selama masa pandemi tetap dapat dipenuhi.

\section{PEMBAHASAN}

Pendidikan merupakan hak dasar bagi setiap warga Negara. Dalam Undang-undang Dasar Negara Republik Indonesia (UUD NRI) Tahun 1945 dalam Pasal 28 C yang berbunyi, "Setiap orang berhak mengembangkan diri melalui pemenuhan kebutuhan dasarnya, berhak mendapat pendidikan dan memperoleh manfaat dari ilmu pengetahuan dan teknologi, seni dan budaya, demi meningkatkan kualitas hidupnya dan demi kesejahteraan umat manusia."

Dalam Pasal 31 Ayat 1 juga menegaskan kembali bahwa "Setiap warga negara berhak mendapatkan pendidikan”. (Rozak, 2019)

Berdasarkan temuan lapangan, pemenuhan hak pendidikan anak yang diperoleh para siswa atau peserta didik di Ciputat, Desa Bojong sudah dianggap terpenuhi meskipun masih terdapat beberapa kelemahan di berbagai sisi akibat keterbatasan yang dihadapi. Jika melihat dari Undangundang tentang hak Pendidikan bagi setiap warga Negara dan melihat dalam teori sebagaimana tolak ukur terpenuhinya kebutuhan manusia terutama yang ditekankan pada bidang pendidikan diperoleh hasil yang baik. Peneliti menemukan bahwa selama masa pandemi, para siswa yang berada di wilayah Desa Ciputat kecamatan Bojong Kabupaten Garut tetap mendapatkan hak pendidikannya meskipun ditengah keterbatasan media belajar secara daring. Pihak sekolah, keluarga dan masyarakat serta pemerintah turut bekerjasama dalam meningkatkan serta mendukung keberhasilan proses belajar mengajar ini. 
Hal ini dapat dibuktikan dari berbagai strategi yang peneliti temukan saat melakukan kunjungan ke lokasi.

1. Pembelajaran tetap dilakukan secara tatap muka dengan pembatasan jumlah peserta yang masuk ke kelas atau dengan dibuat sift. Meskipun proses belajar mengajar tidak dilakukan secara penuh tetapi dengan pemberian tugas tambahan untuk memenuhi target kurikulum dengan bimbingan orangtua atau keluarga dirumah. Pihak guru juga memperbolehkan para siswa datang ke rumah mereka jika ada pelajaran yang belum difahami siswa atau yang perlu untuk ditanyakan.

2. Sebelum pihak sekolah memutuskan untuk melakukan pembelajaran secara luring, setelah melihat kondisi para siswa yang tidak memungkinkan melakukan pembelajaran secara daring, pihak orangtua sebelumnya diundang secara khusus ke sekolah untuk membuat persetujuan dan kesepakatan bersama jika pembelajaran dilakakukan secara luring, tiap-tiap orang tua harus siap bertanggung jawab membimbing anak mereka masing-masing ketika belajar dirumah. Sebab tanpa campur tangan pihak keluarga dirumah, mustahil pembelajaran yang efektif dapat berjalan dengan baik dan lancar.

3. Selain sekolah dan masyarakat, lingkungan yang kondusif juga dapat mendukung sistem pendidikan para siswa. Di Ciputat, terutama semenjak pandemi diberlakukan jam wajib belajar sejak pukul 19.00-21.00 WIB tanpa mobilitas lain dan hanya dirumah saja, pemerintah desa juga menyediakan sebuah lokasi khusus guna memfasilitasi anak-anak belajar kelompok.
Pendidikan

bukanlah pendidikan jika tidak ada belaian sayang di dalamnya. Untuk itu, pendekatan pemenuhan dan perlindungan hak anak sebagai konsep dasar yang harus melandasi pemeliharaan, pengasuhan hingga pendidikan anak diharapkan menjadi langkah cerdas dalam mempersiapkan sebuah generasi emas ke depan. (Hamid, 2018)

\section{Dengan}

demikian, meskipun pembelajaran secara tatap muka dilakukan secara sederhana dan terbatas, Harapannya, para siswa masih tetap dapat meraih pendidikannya dengan baik walaupun dengan cara luring dengan pemberlakuan aturan-aturan yang berlaku guna mencegah penularan Covid-19 serta dikarenakan keterbatasan fasilitas digital para siswa jika harus belajar secara daring sesuai arahan Menteri Pendidikan beberapa waktu yang lalu.

\section{KESIMPULAN}

Berdasarkan data penelitian yang sudah dikumpulkan, maka diperoleh kesimpulan bahwa warga masyarakat di Dusun Ciputat, Desa Bojong Bungbulang Garut memenuhi kebutuhan pendidikan anak dilakukan dengan bekerjasama antar berbagai pihak antara lain sekolah, rumah dan lingkungan masyarakat.

Dengan meningkatkan kerjasama dengan pihak-pihak tersebut, diharapkan perolehan hak pendidikan anak dapat terlaksana dengan maksimal sebab mereka sebagai garda terdepan yang berpengaruh dalam pembentukan karakter anak salah satunya memenuhi kebutuhan mereka selama pandemi saat ini. Hal ini tentunya menjadi sebuah berita baik bahwanya sangat dimungkinkan untuk para siswa di sekolah lain untuk sedikit demi sedikit mencoba mencari strategi agar dapat kembali melakukan pembelajaran di sekolah dengan bertatap muka dengan penerapan aturan-aturan yang berlaku. 


\section{DAFTAR PUSTAKA}

Cresswell, John W. (2009). Qualitative inquiry and research design. United State of America: Sage Publication

Hamid, S. I. (2018). Pemenuhan Dan Perlindungan Hak Anak Dalam Menyongsong Indonesia Emas 2045. Cakrawala Dini: Jurnal Pendidikan Anak Usia Dini, 6(1), 17-22. https://doi.org/10.17509/cd.v6i1.10513

International Labour Organization. (2020). Kebijakan Perlindungan Sosial dalam Merespons Krisis Covid-19 (pp. 1-16).

Kemenkes RI. (2020). Keputusan Menteri Kesehatan Republik Indonesia Nomor Hk.01.07/Menkes/104/2020 Tentang Penetapan Infeksi Novel Coronavirus (Infeksi 2019-Ncov) Sebagai Penyakit Yang Dapat Menimbulkan Wabah Dan Upaya Penanggulangannya. The Open Dentistry Journal, 14(1), 71-72.

Mendikbud. (2020). Surat Edaran Nomor 4 Tahun 2020 Tentang Kebijakan Pendidikan dalam Masa Darurat Penyebaran Covid-19. 4-6.

Rozak, A. (2019). Perlindungan Hak Atas Pendidikan Bagi Pengungsi Internal: Studi Kasus Pendidikan Anak Korban Kekerasan Terhadap Warga Syiah Sampang Abdul. Jurist-Diction, 2(6), 1887-1908.

Tim Kerja Kementerian Dalam Negeri. (2013). Pedoman Umum Menghadapi Pandemi Covid-19 Bagi Pemerintah Daerah: Pencegahan, Pengendalian, Diagnosis dan Manajemen. Journal of Chemical Information and Modeling, 53(9), 16891699.

https://doi.org/10.1017/CBO9781107415 324.004

\section{Sumber Internet:}

https://www.kompas.com/tren/read/2020/03/1 9/073611765/cegah-penularan-viruscoronamengapa-sebaiknya-14-hari-di-rumah-saja https://mediaindonesia.com/read/detail/3167 27-pemerintah-resmi-memperpanjang-masadarurat-covid-19diunduh pada 03 Juni 2020

https://nasional.kompas.com/read/2020/05/22/ 16235491/update-kini-ada-20796-kasuscovid-19-di-indonesia-bertambah-634?page $=1$ diunduh pada 26 Mei 2020

https://news.detik.com/berita/d 4942327/pemerintah-tetapkan-masa-daruratbencana-corona-hingga-29-mei-2020 Diunduh pada 03 Juni 2020 